\title{
Experimental Production of Transgenic Mice Carrying Human $\beta$-globin Genes
}

\author{
Hideaki TOJO, Keiko MOMOI, Yasuyuki FUKUMAKI* \\ and Zen-ich OGITA** \\ Institute for Laboratory Animal Science, **Institute for Oriental \\ Medicine Toyama Medical and Pharmaceutical University, \\ Toyama, 930-01, *Department of Biochemistry, School \\ of Medicine, Kyushu University, Fukuoka, 812, Japan
}

(Received 18 March 1986/Accepted 24 September 1986)

\begin{abstract}
To produce transgenic mice carrying human $\beta$-globin genes, we introduced the following two constructs of the genes to male pronuclei of fertilized mouse eggs: $4.4 \mathrm{~kb}$ Pst I/Pst I sequences of the human $\beta$-globin gene (experiment 1 ) and the human $\beta$ globin gene cluster ( $\operatorname{cosHG} 28$ ) conaining $\mathrm{G} \gamma, \mathrm{A} \gamma, \delta$ and $\beta$-globin genes and cosmid vector pJB8 (37.5 kb, experiment 2). In experiment 1,25 mice were born, and four (one female and three males) carrying the injected gene sequences were identified. One of these mice carried the entire sequence of the human $\beta$-globin gene but three others appeared to carry only a part of the entire sequence. The mouse with the entire sequence showed a slight increase in the minor component of the mouse $\beta$-globin chain in the same position as the human $\beta$-globin chain. In experiment 2, 61 mice were born, and nine (three females and six males) carried the sequences of the injected gene. However, from DNA analysis, no appropriate sequences present within the A $\gamma$ or $\beta$-globin gene were identified in any of the founder mice. In this case, DNA fragments of the gene cluster that were digested in the mouse nucleus after microinjection of the gene might be integrated into host DNA.
\end{abstract}

In recent years, various cloned genes have been introduced into the mouse germ line by directly microinjecting them into the pronucleus of a zygote. This method allows a variety of foreign DNA molecules to be introduced into all cells of experimental animals. A number of foreign genes have been expressed in transgenic mice. Brinster et al [1] have identified various factors affecting the efficiency of introducing foreign DNA into mice by microinjection. Since then, transgenic mice have become routine models for the study of biological problems in mammals. If this technique could be used for other laboratory animals and farm animals, it would be of great practical and economic value, allowing the transfer of characteristics from one breed to another much more rapidly than by conventional breeding. It could allow us genetic tranfer even between species. Hammer et al. [2] demonstrated that it was possible to use the microinjection technique to obtain integration of foreign DNA into the genome and expression of exogenous DNA in large animals. We report here on transgenic mice carrying human $\beta$-globin genes that were produced by microinjecting DNA into the pronuclei of fertilized eggs. 


\section{Materials and Methods}

DNA construct for microinjection: Two constructs of human $\beta$-globen genes were used : a $4.4-\mathrm{kb}$ Pst I/Pst I fragment of human $\beta$ globin gene (experiment 1) and cosHG28 (experiment 2), linearized by cleavage with Kpn I. CosHG28 contains G $\gamma, \mathrm{A} \gamma, \delta$ and $\beta$ globin genes $(37.5 \mathrm{~kb})$ and the cosmid vector pJB8 (Fig. 1).

Collection of egges for microinjection: Fertilized eggs were obtained from the oviducts of superovulated $\mathrm{F} 1$ females $(\mathrm{C} 57 \mathrm{BL} / 6 \times \mathrm{DBA} /$ 2) mated at the proper time with males of the same strain. Eggs were freed from the cumulus cells with hyaluronidase ( $1 \mathrm{mg} / \mathrm{m} l$ of medium), washed several times in fresh medium and stored in an atmosphere of $5 \% \mathrm{CO}_{2}$ and $95 \%$ air at $37^{\circ} \mathrm{C}$ until microinjection.

Microinjection of DNA: The instruments for microinjection consisted of two micromanipulators (Narishige Sci. Inst. Lab., Model 102) connected to an inverted microscope with Nomarski optics (Nikon, Diaphot-TMD). A small drop of Hoppe and Pitts's medium [3] containing eggs and of DNA solution for micro-
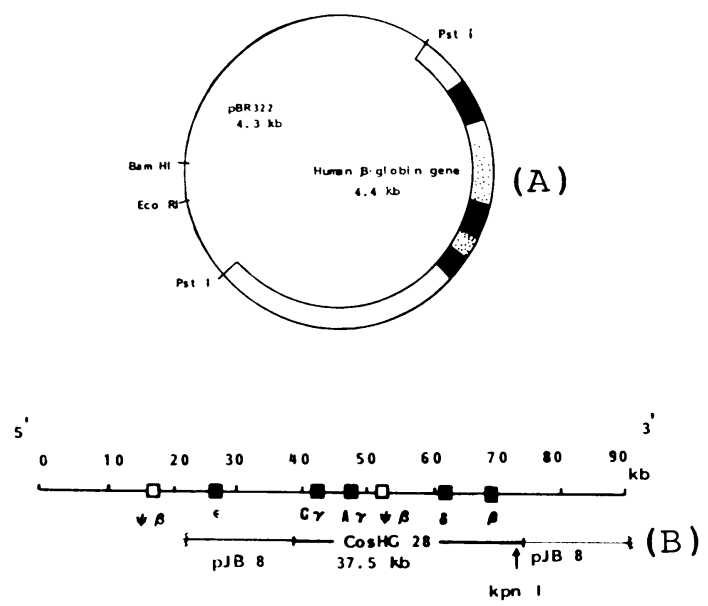

$\mathrm{A}$ : Human $\beta$-globin gene $(4.4 \mathrm{~kb})$ inserted into plasmid pBR $322(4.3 \mathrm{~kb})$ at the Pst I site (exp. 1).

$B$ : Human $\beta$-globin gene cluster inserted into cosmid pJB8, containing $\mathrm{G}_{\gamma}, \mathrm{A}_{\gamma}, \beta$, and $\beta$ globin genes.

Fig. 1. Constructs of fuman $\beta$-globin genes microinjected into the pronucleus of a mouse zygote. injection were placed on a special slide and covered with paraffin oil. A small volume of DNA solution was drawn into the injecting pipet, which was then moved to the drop containing the eggs. An egg was positioned onto the holding pipet so that the male pronucleus was in juxtaposition with the injection pipet for subsequent injection of DNA solution into the pronucleus. Approximately 800 (exp. 1) or 1,200 (exp. 2) copies of the gene per egg were injected into 367 eggs. After about one hour of incubation, 240 undamaged eggs were transferred into the oviducts of 13 pseudopregnant ICR (random-bred) females mated on the previous night with vasectomized males.

DNA analysis: Mice that had integrated the injected DNA were detected by DNA hybridization to nucleic acids isolated from either the spleen or liver. The spleen or liver was removed at 8-11 weeks of age and homogenized in SET buffer (1\% SDS, $5 \mathrm{mM}$ EDTA, $10 \mathrm{mM}$ Tris- $\mathrm{HCl}, \mathrm{pH}$ 7.5) containing proteinase $\mathrm{K}(100 \mu \mathrm{g} / \mathrm{m} l)$, incubated for two hours at $37^{\circ} \mathrm{C}$, and then left at room temperature for another 24 hours. The homogenate was subsequently extracted once with phenol, twice with phenol/chloroform and once with chloroform/ isoanylalcohol. The extract was dialyzed against $10 \mathrm{mM}$ Tris- $\mathrm{HCl}(\mathrm{pH} 8.0), 10 \mathrm{mM} \mathrm{NaCl}$ and $1 \mathrm{mM}$ EDTA and precipitated with two volumes of ethanol. The precipitated DNA was dissolved in 'TE buffer (10 mM Tris- $\mathrm{HCl}, 10 \mathrm{mM}$ EDTA, $\mathrm{pH}$ 7.5).

Ten $\mu \mathrm{g}$ of tissue DNA was digested with appropriate restriction enzymes at $37^{\circ} \mathrm{C}$, and samples were electrophoresed on $1 \%$ agarose in buffer ( $\mathrm{pH} \mathrm{8.0).} \mathrm{DNA} \mathrm{fragments} \mathrm{were} \mathrm{then}$ transferred to nitrocellulose filters according to the method of Southern [4]. Nick translations we:se performed by using the Nick Translation Kit with 32p-labeled CTP obtained from New England Nuclear Cot Ltd. DNA fragments were hybridized to specific probes derived from human $\beta$-globin genes (exp. 1) or $\mathrm{Ar}$ - and $\beta$ globin genes (exp. 2).

RNA analysis: Total RNAs were isolated from the liver and bone marrow cells of founder mice according to the guanidinium/cesium chloride method [5]. Tissues were sliced on dry ice and mixed with five volums of guanidinium 
isothiocyanate solution (6 $\mathrm{M}$ guanidinium isothiocyanate, $5 \mathrm{mM}$ sodium citrate, $\mathrm{pH} 7.0,0.1$ M $\beta$-mercaptoethanol, $0.5 \%$ sarkosyl). After adding $1 \mathrm{~g}$ of cesium chloride to each $2.5 \mathrm{~m} l$ of the homogenate, the mixture was laid onto a solution of $5.7 \mathrm{M} \mathrm{CsCl}$ in $0.1 \mathrm{M}$ EDTA $(\mathrm{pH}$ 7.5) in a centrifuge tube and then centrifuged at $35,000 \mathrm{~g}$ for 12 hours at $20^{\circ} \mathrm{C}$. The RNA pellet at the bottom of the tube was dissolved in TE buffer and precipitated with 2.2 volumes of cold ethanol. RNA was stored in $70 \%$ ethanol at $-70^{\circ} \mathrm{C}$.

Denaturing of RNA and dot spotting onto the nitrocelullose filter were done according to the method of Brinster et al. [1]. Hybridization with the DNA probe was carried out according to the method of Southern blotting [4].

Analysis of $\beta$-globin: Human $\beta$-globin protein in transgenic mice was detected by isoelectrofocusing. Total globin was prepared from anticoagulated blood by the acid-acetone procedure. One hundred $\mu \mathrm{g}$ of the globin sample was dissolved in $8 \mathrm{M}$ urea, $10 \% 2-$ mercaptoethanol and focused on $6 \%$ polyacrylamide slab gels containing $8 \mathrm{M}$ urea, $2 \%$ pharmalyte, $\mathrm{pH}$ 6.5-9.0, $0.4 \%$ pharmalyte, $\mathrm{pH}$ $4-6.5$, and $5 \%$ glycerol. The gels were stained with Coomassie brilliant blue.

\section{Results}

In experiment 1 , a $4.4 \mathrm{~kb}$ Pst I/Pst I sequence of a $\beta$-globin gene was introduced into 367 eggs, and 240 eggs (65.4\%) survived. Twenty-five mice were born and four (one female and three males, No. 12-2, 12-3, 12-4, $13-1)$ carrying $\beta$-globin gene sequences were identified. Figure 2 shows the hybridization pattern obtained by digestion of spleen DNA with two separate restriction enzymes. A $32 \mathrm{p}-$ labeled Pst I/Pst I fragment of a $\beta$-globin gene was used as a probe. In four mice, Eco RI digest gave a band with an estimated size of $4.5 \mathrm{~kb}$ that hybridized to the probe. Bam HI digestion of mouse No. 12-3 DNA produced a $1.9-\mathrm{kb}$ fragment that hybridized to the probe. This fragment corresponds to the region from the $5^{\prime}$-flanking sequence to the second axon of of the $\beta$-globin gene. The three other mice
(12-2, 12-4 and 13-1) did not show the Bam HI fragment of this size. It is possible that these mice contained only a part of the entire sequences. Lacy et al. [6] also described a similar case in their study introducing rabbit $\beta$-globin genes into mice. In isoelectrofocusing analysis, mouse No. 12-3 showed a slight increase in the minor component of the mouse $\beta$-globin chain in the same position as the human $\beta$-globin chain, whereas there was a

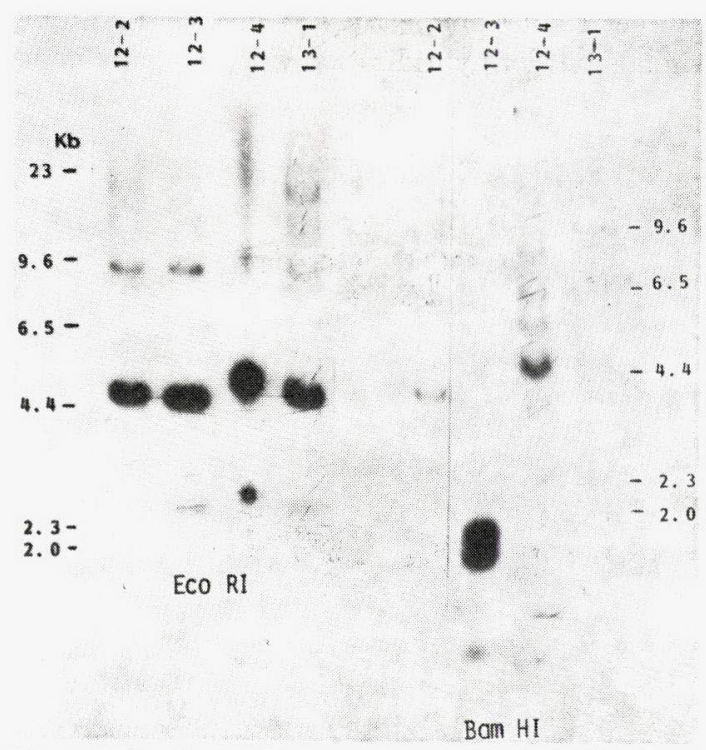

Fig. 2. Southern blotting analysis of DNA from mice with human $\beta$-globin gene.

DNA digests were hybridized with a $32 \mathrm{p}$-labeled Pst I/Pst I sequence of $\beta$-globin gene.

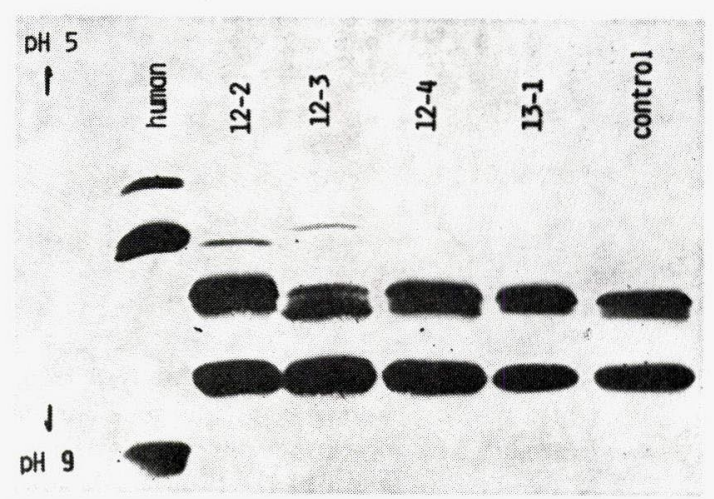

Fig. 3. Isoelectrofocussing of hemolysates from transgenic mice with human $\beta$-globin gene. Mouse No. 12-3 carried the entire sequence of the gene. 
decrease in the major component of mouse $\beta$ globin, as shown in Fig. 3. This may show an expression of a human $\beta$-globin gene in the blood cells of this mouse. However, we failed to detect the transcript of the gene in bone marrow cells from this mouse by Northern blotting analysis.

In experiment 2, when the linearized cosHG28 DNAs were microinjected into 830 eggs, 61 pups were born form 520 (62.6\%) surviving eggs. Liver DNAs from nine mice (three females and six males) that gave positive signals on dot hybridization with a globin gene

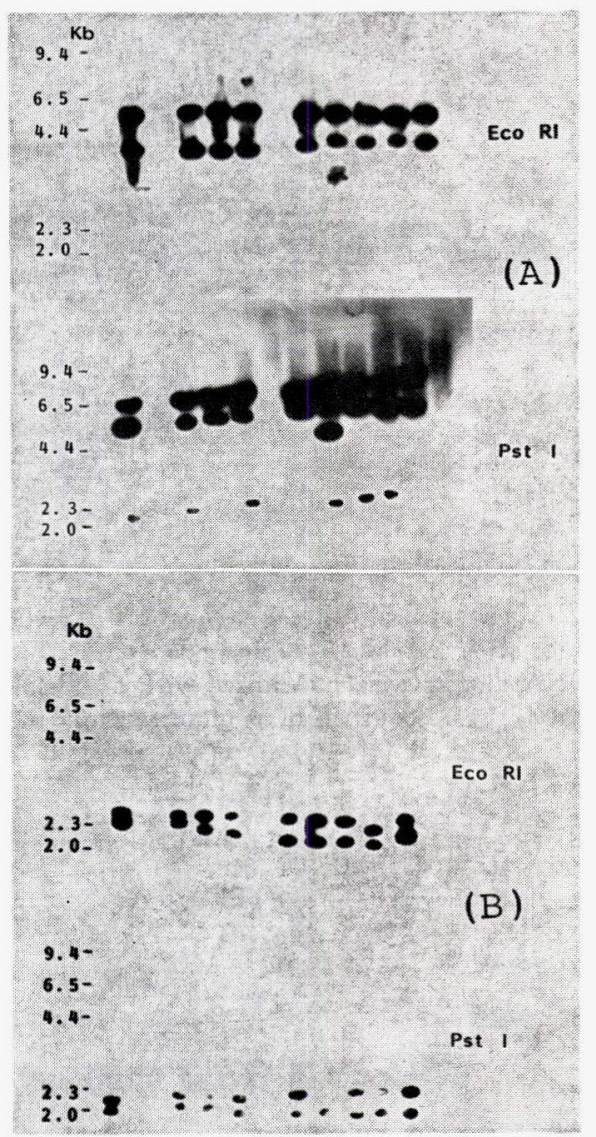

Fig. 4. Southern blotting analysis of DNA from mice into which a human $\beta$-globin gene cluster was introduced.

DNA digests were hybridized with a $32 \mathrm{p}$-labeled Hind III/Hind III sequence of an A $\gamma$-globin gene (A) and a Pst I/Pst I sequence of a $\beta$ globin gene (B). Lanes 2 and 6 from the left were negative mice. probe were digested with Eco RI or Pst I. Each digest was hybridized with $32 \mathrm{p}$-labeled circular $\beta$-or Ar-globin genes containing plasmid vectors. The results are shown in Fig. 4. The Eco RI digests gave $3.0-\mathrm{kb}$ and $2.8-\mathrm{kb}$ fragments when hybridized with the $\beta$-globin probe and $4.0-\mathrm{kb}$ and $6.0-\mathrm{kb}$ fragments with the A $\gamma$-probe. On the other hand, Pst I digests showed 2.5-kb and 2.3-kb fragments with the $\beta$-probe, and $7-\mathrm{kb}, 5-\mathrm{kb}$ and $2.0-\mathrm{kb}$ fragments with the Ar-probe. One mouse had an additional 4.4-kb fragment hybridized with the A $\gamma$-probe. However, no appropriate fragments present within $\mathrm{A} \gamma$ - and $\beta$-globin gene sequences were identified in any of the founder mice. The results indicated that neither entire sequences of the gene cluster nor intact $\mathrm{A} \gamma$ - and $\beta$-globin gene sequences were integrated into mouse DNA in this experiment.

\section{Discussion}

Since Gordon et al. [7] first reported on transgenic mice carrying recombinant DNA obtained by directly microinjecting DNA into the pronucleus of the mouse zygote, a number of foreign genes have been introduced into the mouse germ line. However, the conditions that influence success with this technique have not been well identified. Recently, Brinster et al. [1] determined some important factors that affect successful integration of foreign DNA into host chromosomes. They showed that the optimal conditions for integration entailed injection of a few hundred linear molecules into the male pronucleus of a fertilized one-cell egg and that the overall efficiency also depended on the choice of mouse strain. Our microinjection procedures were subjected to the conditions identified by Brinster et al. [1].

The human $\beta$-globin gene family provides an attractive model for the study of gene regulation in developmental processes, because much of the work on regulation of gene expression has concentrated on globin genes, and their expressions are subjected to both tissue- and stage-specific regulation. A variety of natural mutations affecting globin gene expression have been defined and characterized. Therefore, 
transgenic mice which expressed foreign $\beta$ globin genes should be desirable models for this study. Several investigators have introduced various constructs of $\beta$-globin genes into mice by microinjecting techniques $[6,8-10]$. However, in most of these cases, the injected genes were either not expressed or expressed in inappropriate tissues. The poor expression of foreign globin genes in some of these cases may have been due to inclusion of procaryotic vector DNA. Chada et al. [11] achieved tissue-specific expression of the human $\beta$-globin gene in transgenic mice by introducing hybrid mouse/human $\beta$-globin genes, but the level of expression was only $2 \%$ of endogenous mouse $\beta$-globin mRNA. On the other hand, Townes et al. [12] introduced linear human $\beta$-globin genes with various sequences of the promotor region into fertilized eggs and showed that the construct with only $48 \mathrm{bp}$ of the $5^{\prime}$-flanking sequence was still expressed (10\% of normal $\beta$-globin) appropriately in one transgenic mouse. This was a surprising observation because removal of the tandemly related sequences in the -100 region and the CCAAT box in the -70 region severely depressed the level of $\beta$-globin gene expression in transient assay systems using heterologous cells [13].

In the present study, the human $\beta$-globin gene used in the first experiment included the $5^{\prime}$-flanking region and the entire structure gene essential for its expression. It appeared that the entire sequence of the gene was expressed in one transgenic mouse. However, transcript from the gene could not be detected in bone marrow cells of this mouse. This discrepancy may be due to a low level of transcription of the $\beta$-globin gene in this mouse, in addition to a mosaic with this gene present on a minority of somatic cells. Previous works $[14,15]$ have indicated that the integration of the foreign gene into the mouse egg after first cleavage occurred in only some somatic cells, presumably because gene integration was delayed. By contrast, in the case of introducing the human $\beta$-globin gene cluster to the mouse egg, no mice carried the intact sequence of the injected gene. DNA fragments of the gene cluster that were digested in the mouse pronucleus after microinjecteion of the DNA might be integr- ated into mouse DNA. It is suggested that a larger gene construct or the presence of either a homologous region or repetitive sequences with in the cluster might disturb the integration of the entire sequence. Therefore, we should further explore techniques for introducing genes with large sequences into mouse germ lines.

\section{Acknowledgements}

We thank Dr. R. A. Fravell, Biogen Research Corporation, 14 Cambridge, Massachusetts UK for providing the human $\beta$-gobin gene with pBR322 and CosHG28. This work was supported in part by a grant-in-aid for scientific research from the Ministry of Education, Science and Culture of Japan (No. 59480416).

\section{References}

[ 1 ] Brinster, R. L., Chen, H. Y., Trumbauer., M. E., Yagle, M.K., and Palmiter, R.D. (1985). Factors affecting the efficiency of introducing foreign DNA into mice by microinjecting eggs. Proc. Natl. Acad. Sci., 82, 4438-4442.

[2] Hammer, R.E., Pursel, V.G., Rexroad, C.E., Wall, R.J., Blot, D.J., Ebert, K.M., Palmiter, R.D., and Brinster, R.L. (1985). Production of transgenic rabbits, sheep and pigs by microinjection. Nature, 315, 680-683.

[ 3 ] Hoppe, P.C., and Pitts, S. (1973). Fertilization in vitro and development of mouse ova. Biol. Reprod., 8, 420-426.

[4] Southern, E. M. (1975). Detection of specific sequences among DNA fragments separated by gel electrophoresis. J. Mol. Biol., 93, 503-517.

[5] Thomas, P.S. (1980). Hybridization of denatured RNA and small DNA fragments transferred to nitrocellulose. Proc. Natl. Acad. Sci., 77, 52015205.

[6] Lacy, E., Robert, S., Evans, E.P., Burtenshaw, M.D., and Costantini, F. (1983). A foreign $\beta$ globin gene in transgenic mice: integration at abnormal chromosomal positions and expression in inappropriate tissues. Cell, 34, 343-358.

[ 7 ] Gordon, J. W., Scangos, G. A., Plotkin, D. J., Barbosa, J.A., and Ruddle, F.H. (1983). Genetic transformation of mouse embryos by microinjection of purified DNA. Proc. Natl. Acad. Sci., 77, 7380-7384.

[8] Wagner, E. F., Stewart, T. A., and Mintz, B. (1981). The human $\beta$-globin gene and a functional viral thymidine kinase gene in developing mice. Proc. Natl. Acad. Sci., 78, 5016-5020.

[9] Wagner, T. E., Hoppe, P. C., Jollick, J. D., Hodinka, R.L., and Gault, J.B. (1981). Microinjec- 
tion of a rabbit $\beta$-globin gene into zygotes and its subsequent expression in adult mice and their offspring. Proc. Matl. Acad. Sci., 78, 6376-6380.

[10] Costantini, F., and Lacy, E. (1981). Introduction of a rabbit $\beta$-globin gene into the mouse germ line. Nature, 294, 92-94.

[11] Chada, K., Magram, J., Paphad, K., Radice, G., Lacy, E., and Costantini, F. (1980). Specific expression of a foreign $\beta$-globin gene in erythoid cells of tronsgenic mice. Nature, 314, 377-380.

[12] Townes, T.M., Lingrel, J.B., Chem, H.Y., Brinster, R.L., and Plamiter, R.D. (1985). Erythroidspecific expression of human $\beta$-globin genes in transgenic mice. EMBO. J., 4, 1715-1723.
[13.] Wright, S., deBoer, E., Grosveld, F. G., and Flavell, R. A. (1983). Regulated expression of the human $\beta$-globin gene family in murine erythroleukemia cells. Nature, 305, 333-335.

[14] Wagner, E. F., Covarrubias., L., Stewart, T. A., and Mintz, B. (1983). Prenatal lethalities in mice homozygous for human growth hormone gene sequences integrated in the germ line. Cell, 35, 647-655.

[15.] Palmiter, R.D., Wilkin, T.M., Chen, H.Y., and Brinster, R. L. (1984). Transmission distortion and mosaicism in an unusual transgenic mouse pedigree. Cell, 36, 869-877.

\section{ヒト $\beta$ ーグロビン遺伝子の導入による \\ トランスジェニックマウスの作出}

東條英昭·桃井啓子・服巻保幸* ·荻田善一**

富山医科薬科大学動物実験センター

*九州大学医学部生化学教室

$* *$ 富山医科薬科大学和漢薬研究所病態生化学部門

ヒト $\beta$-グロビン遺伝子の導入によるトランスジェニ ックスマウスを作出するために，ヒト $\beta$-グロビン遗伝 子 $(4.4 \mathrm{~kb})$ 打よびヒト $\beta$-グロビン遺伝子群 $(\mathrm{G} \gamma, \mathrm{A} \gamma$, $\delta, \beta: 37.5 \mathrm{~kb})$ をマウス受精卵の雄性前核に顕微注入 した。卵は偽妊娠マウスの卵管へ移植した。生まれたマ ウスの脾臓または肝缄から DNA を抽出し, サザン法に より注入遗伝子のマウス DNA への插入を調べた。前者 では，生まれた 25 匹のうち 4 匹で遗伝子の插入が確認
された。そのうち1匹に打いて，ヒト $\beta$-グロビン遺伝 子の全領域 $(4.4 \mathrm{~kb})$ が插入されており, 等電点電気泳 動による赤血球グロビンの解析の結果, ヒト $\beta$-グロビ ンの産生が示唆された。後者では, 61 匹 9 匹に打いて 遗伝子の挿入が認められたが，それらは全て注入した遭 伝二の一部 DNA 断片であるてが観察され，発現は認め ら机なをった。 